Research Article

\title{
Insulin induced down regulation of the progesterone receptor number in neutrophils in the synthesis of maspin in breast cancer
}

\begin{abstract}
Purpose: The binding of either progesterone or insulin to their specific receptors on neutrophils has been reported to stimulate nitric oxide (NO) induced maspin synthesis in these cells. Experiments were carried out to determine the role of progesterone receptor interaction in the nitric oxide induced maspin synthesis in neutrophils that was preincubated with insulin.
\end{abstract}

Methods: progesterone receptor positive ( $\mathrm{PR}+$ ), progesterone receptor negative ( $\mathrm{PR}-$ ) neutrophils were isolated from the blood cancer subjects. Maspin was determined by enzyme linked immunosorbent assay after in vitro translation of maspin mRNA. NO was determined by methemoglobin method.

Results: Immunohistochemical studies of progesterone receptor (PR) demonstrated the presence of progesterone receptor in the normal peripheral neutrophils and less in number in PR+ breast cancer neutrophils. In contrast, PR- breast cancer neutrophils lacked the progesterone receptor, suggesting pathophysiological defects in the synthesis of PR protein in peripheral PR-neutrophils.

It was also found that as a result of incubation of neutrophils with insulin the binding affinity for progesterone to its receptor in normal neutrophils remained essentially unchanged which demonstrated $\mathrm{Kd}=47.619 \mathrm{nM}$ compared to $\mathrm{Kd}$ of the binding of progesterone is $46.08 \mathrm{nM}$ in the normal neutrophils that were not pretreated with insulin. The progesterone receptors which were $11.5 \times 10^{10} / \mathrm{cell}$ in the untreated cells was found to be decreased to $8.2 \times 10^{1 \%} / \mathrm{cell}$ $(\mathrm{p}<0.005, \mathrm{n}=6)$ after the same cell were treated with $200 \mu \mathrm{U}$ of insulin.

The reduction of PR number on normal neutrophils due to the pretreatment with insulin resulted in the decreased NO induced maspin synthesis from $2.329 \pm 0.012 \mathrm{nM}$ to $1.410 \pm 0.002 \mathrm{nM}$. Decreased PR number in PR+ breast cancer neutrophils due to disease condition and pretreatment with insulin reduced the maspin synthesis from $1.138 \pm 0.024 \mathrm{nM}$ to $0.555 \pm 0.003 \mathrm{nM}$ compared to normal control.

Conclusion: These results suggested that insulin down regulated maspin synthesis in normal and in breast cancer neutrophils by decreasing the progesterone receptor number in both cases.

Keywords: breast-cancer, progesterone, progesterone receptor, insulin, maspin, nitric oxide, neutrophils
Volume 4 Issue 5- 2016

Karabi Ganguly Bhattacharjee,' Asru K Sinha'

'Department of Biomedical Engineering, JIS College of Engineering, India

${ }^{2}$ Sinha Institute of Medical Science \& Technology, India

Correspondence: Karabi Ganguly, 38/ A, Motijheel Avenue, Ist Floor, Kolkata-700074, West Bengal, India, Email karabiganguly73@gmail.com

Received: March 20, 2016 | Published: May 03, 2016

\section{Introduction}

It is reported that a classical model for progesterone dependant condition is the breast cancer tissue in women. ${ }^{1}$ However the hormonal aberrations that promote the development of breast cancer remain unclear, ${ }^{2}$ and the breast cancer risk is associated with the phases like the early onset of menarche, late menopause or post menopausal obesity. ${ }^{3,4}$ The progesterone has been both positively and negatively related to the development of the malignancy. ${ }^{1}$ The expression of the effect of the steroid hormones is reported to be mediated through the binding of the hormones to the nuclear receptors, and a DNA binding domain which recognizes a sequence of DNA known as hormone responsive elements (HRE).

The progesterone receptor status has prognostic significance. ${ }^{6}$ The breast cancer tumors that had no receptors of progesterone are reported to results in worse prognostic outcome than those in cases where the receptor of this hormone was present. ${ }^{7}$ On the basis of presence progesterone receptor in the lesion the breast cancer patients are classified into two groups: (1) progesterone receptor positive $(\mathrm{PR}+)$ and (2) Progesterone receptor negative $(\mathrm{PR}-)$. The presence of progesterone receptor $(\mathrm{PR}+)$ is a better prognostic indicator for the breast cancers. ${ }^{8}$ In contrast the progesterone receptor negative (PR-) tumors have been reported to have a poorer prognosis than that of the progesterone receptor positive $(\mathrm{PR}+)$ tumors. ${ }^{9}$ It is seen that in patients with $\mathrm{PR}+$ tumors the occurrence of metastases is 3-6 times less probable than in patients with PR- tumors. ${ }^{10}$ The clinical data indicated that the PR- breast cancers are less sensitive to therapy than those with $\mathrm{PR}+$ tumors, and $\mathrm{PR}-$ patients had a shorter Disease free interval than those of PR+ patients. ${ }^{11}$

Taking these reports together it could be suggested that progesterone plays important role in both the control of breast cancer, and in the better prognostic outcome of the malignancy. ${ }^{1}$ As discussed above although progesterone and its receptors could have critical role in the development and in the prognostic outcome of the human breast cancer, the role of this steroid in relation to the receptor ligand interaction in the synthesis of maspin remains obscure and 
contradictory. ${ }^{12}$ The physiologic events that influence the effect of one ligand through its binding to its own receptors resulted in the binding and in the consequent effect of a second ligand to its own receptors are generally called "cross talk" between the receptors. ${ }^{13-17}$ We report here that progesterone and insulin were capable of stimulating maspin synthesis through the production of NO in neutrophils. The results of the investigation that suggested the existence of "cross talk" between the receptors of insulin with those of the progesterone in neutrophils, in the context of NO induced maspin synthesis effected by the steroid and the possible pathological implication of the crosstalk in the synthesis of the anti-breast cancer protein in human breast cancer are presented herein. ${ }^{18-20}$

\section{Materials and methods}

\section{Ethical clearance}

The protocol used in the study was approved by the Internal Review Board, Sinha Institute of Medical Science and Technology. Appropriate permission was also obtained from the I.R.B. for the use of rabbits in the studies.

\section{Chemicals}

Recombinant Human maspin (rh Maspin) was a kind gift of Dr. Sally Twining, Dept. of Biochemistry, Medical College of Wisconsin, USA. ELISA maxisorp plates were obtained from NUNC, Denmark. Progesterone and other chemicals used were from Sigma Chemical Co.USA. Progesterone antibody was obtained from Thermo Fisher Scientific, NY, USA.

\section{Preparation of progesterone and insulin solution}

Progesterone and Insulin solution were prepared by dissolving the compounds in $0.9 \% \mathrm{NaCl}$, at $\mathrm{pH} 7.4$.

\section{Selection of patients with breast cancer and normal volunteers}

Only female breast cancer patients between 35-65 years (mean 45years, $n=20$ ), participated in the study. None of them had received any therapy. Equal number of age matched normal female volunteers compared to that of the selected breast cancer subjects were asked to kindly participate in the study.

\section{Determination of progesterone receptor status of neutrophils from breast cancer subjects}

PR statuses were determined by immunohistochemical techniques using fluorescence tagged antibodies and cells were observed and photographed. The neutrophils of the breast cancer subjects were classified as PR+ neutrophils or PR- neutrophils. ${ }^{19}$

\section{Collection of blood}

The blood samples $(20-25 \mathrm{ml})$ were collected by venipuncture and anticoagulated by gently mixing 1 vol.of $0.13 \mathrm{M}$ sodium citrate with 9 vol. of blood. ${ }^{20}$

\section{Immunization of the animals}

Polyclonal antibodies against r-human maspin, progesterone, were raised by repeated immunization in White New Zealand rabbit. ${ }^{21}$

\section{Assay of NO}

Nitric oxide formation was assayed by methemoglobin method by following the protocol described before by using a Beckman Spectrophotometer. ${ }^{22}$
Preparation of neutrophil suspension and the incubation of the isolated neutrophils with progesterone and insulin

Neutrophils isolated from the citrated blood samples suspended in HBBS buffer at $\mathrm{pH} 7.4\left(6 \times 10^{9} \mathrm{cells} / \mathrm{L}\right)^{23}$ were incubated for $2.5 \mathrm{~h}$ at $23^{\circ} \mathrm{C}$ with $200 \mu \mathrm{U}$ of porcine insulin to reach equilibrium then were again incubated with different concentrations of progesterone and another set of neutrophils incubated with different concentrations of only progesterone for $4 \mathrm{~h}$ at $37^{\circ} \mathrm{C}$ under sterile conditions.

\section{In vitro translation of maspin-mRNA}

Nucleic acids containing maspin mRNAs were isolated by Trizol methods from the neutrophils and were incubated with ribosomal preparation, mixture of all amino acids $(0.1 \mu \mathrm{mol}$ each $/ \mathrm{mL})$ and $2 \mathrm{mM}$ ATP for $6 \mathrm{~h}$, was centrifuged at $10,000 \mathrm{~g}$ for $10 \mathrm{~min}$ at $0^{\circ} \mathrm{C}$. The supernatant was used for the determination of maspin by ELISA. ${ }^{24,25}$

\section{Enzyme linked immunosorbant assay (ELISA) for Maspin}

Maspin was quantitated by ELISA using polyclonal antibody developed against rh Maspin. ${ }^{26}$

Scatchard plot analysis of the equilibrium binding of progesterone to its receptor in neutrophils

The neutrophils with the bound progesterone were separated from the unbound hormones by filtration over GF/C filter. The concentrations of progesterone in the sample were determined by ELISA. The dissociation constant (Kd) and the receptor numbers (n) were determined from Scatchard plots. ${ }^{27}$

\section{Statistical analyses}

The results obtained are presented as mean $\pm \mathrm{SD}$. The significance of the results was determined by Students't-test, and $p<0.005$ was considered to be significant.

\section{Results}

\section{Determination of progesterone receptor in normal, PR+, PR- in peripheral neutrophils in blood}

Immunohistochemical studies of the statuses of progesterone receptor in PR+ neutrophils and in the normal peripheral neutrophils demonstrated the presence of progesterone receptors. In contrast, the PR- neutrophils from the breast cancer patients showed the absence of PR, suggesting pathophysiological defects in the synthesis of progesterone receptors proteins in the peripheral neutrophils (Figure $1)$.

The Figure 1 presented is representative of six or more experiments using neutrophils from six different subjects from each group. The immunohistochemistry of the PR was determined as described in the Methods section. The cells are observed under 45Xobjective.

\section{Scatchard plot of the equilibrium binding of progesterone to intact normal neutrophils}

Scatchard plot of the equilibrium binding of progesterone to normal neutrophils demonstrated typical homogeneous progesterone receptor population (Line A in Figure 2). The analysis of the binding characteristics showed there were $11.5 \pm 1.011 \times 10^{10}$ progesterone receptor binding sites/cell, with dissociation constant (Kd) 47.619nM. 

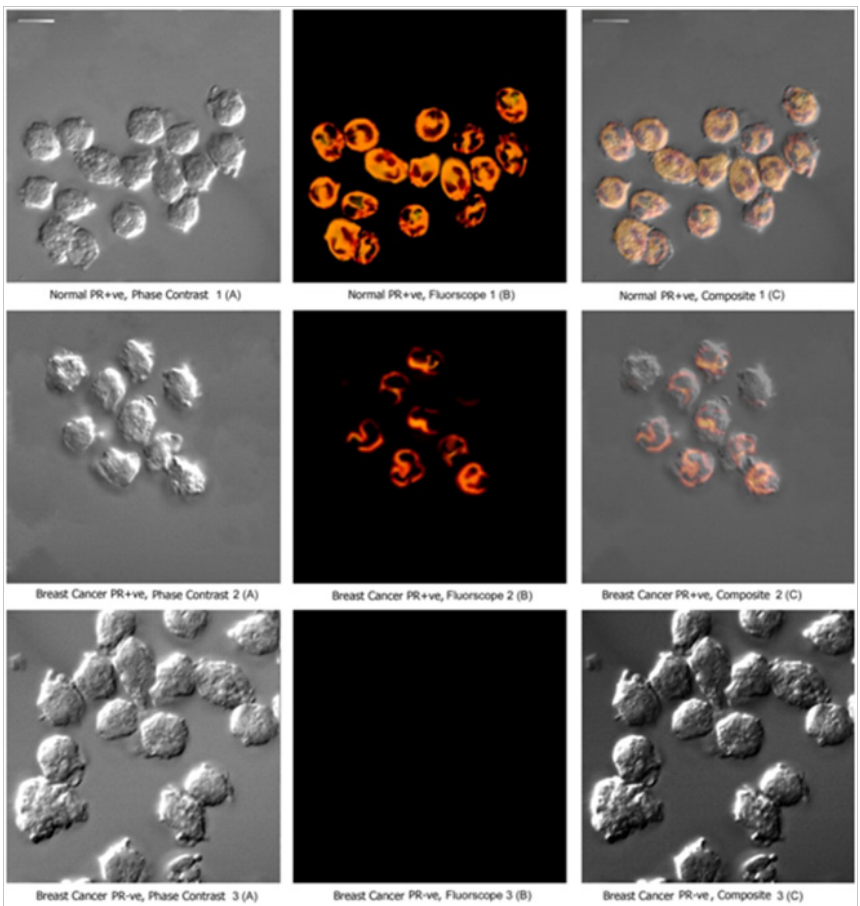

Figure-1

\section{Effect of pre incubation of neutrophils with insulin on the binding of progesterone to its receptors on these cells}

Scatchard plot of the equilibrium binding of progesterone to the neutrophils pre incubated with insulin was constructed (Line B in Figure 2) and compared with that constructed using neutrophils that were not pre incubated with insulin (Line A in Figure 2). It was found that as a result of incubation of neutrophils with insulin the binding affinity for progesterone to its receptors in neutrophils remained essentially unchanged which demonstrated $\mathrm{Kd}=46.08 \mathrm{nM}$ compared to $\mathrm{Kd}$ of the binding of progesterone is $47.619 \mathrm{nM}$ in the neutrophils that were not pretreated with insulin. The progesterone receptors which were $11.5 \pm 1.011 \times 10^{10} /$ cell in the untreated cells was found to be decreased to $8.2 \times 10^{10} / \mathrm{cell}(\mathrm{p}<0.005, \mathrm{n}=6)$ after the same cell were treated with $200 \mu \mathrm{U}$ of insulin.

\section{The effect of progesterone on the synthesis of NO and maspin in normal PR+ and PR- neutrophils pre incubated with insulin}

It was found that the pre incubation of normal PR + neutrophils with insulin resulted in the significant impairment of the synthesis of both NO and maspin in these cells when compared to the control (Table 1). The treatment of PR- neutrophils which failed to produce either NO or maspin when treated with estrogen also failed to produce these agents when these cells were pretreated with insulin.

\section{The effect of progesterone on the synthesis of NO and maspin in Breast Cancer PR+ and PR- neutrophils pre incubated with insulin}

It was found that the pre incubation of breast cancer PR + neutrophils with insulin resulted in the significant furthermore impairment of the synthesis of both NO and maspin in these cells when compared to the control (Table 2). The treatment of breast cancer PR- neutrophils which failed to produce either NO or maspin when treated with progesterone also failed to produce these agents when these cells were pretreated with insulin.

\section{Discussion}

Hormones through their specific binding sides on the cell surface implicate their specific effects in the target cells. Expression of the hormone effects depends on the ligand (hormone) receptor binding. The 'cross talk' between the hormone receptors may significantly either increase or decrease the activity of unrelated hormones in the system. Insulin, a hypoglycemic hormone has its specific functions, in this case influenced the activity of progesterone which is known to induce the synthesis of maspin, an anti breast cancer protein through the NO synthesis in normal as well as from the breast cancer neutrophils. PR- reported to produce worse prognostic outcome of the disease when compared to that in $\mathrm{PR}+$ breast cancer neutrophils. ${ }^{9}, 10,28$

It is also reported that NO induced maspin synthesis is significantly less in PR+ neutrophils isolated from breast cancer subjects compared to that of normal. ${ }^{19}$ Again, preincubation with insulin of PR + neutrophils either isolated from breast cancer subjects or from normal individuals depicted down regulation of progesterone receptor number which in turn resulted in the impairment of NO induced maspin production by progesterone. In this study, binding of insulin to its receptors cause reduced binding (down regulation) of the progesterone to its receptors by decreasing the number of progesterone receptors on the cell surface. As insulin reduces the number of progesterone receptors, it is 
called heterologous down regulation. In our study, the effect of insulin represented a case of heterologous down regulation of progesterone receptors in neutrophils mediated through an apparent 'cross talk' between different receptors. ${ }^{29}$

It has been reported that $\mathrm{PR}+$ neutrophils from the breast cancer patients produced less amount of NO induced maspin synthesis compared to normal control again the pre incubation of $\mathrm{PR}+$ neutrophils with insulin resulted in the down regulation of progesterone receptor number in the intact neutrophils that resulted in the impairment of NO induced maspin production by this steroid hormone. Our results implied that the systemic presence of insulin might adversely affect the systemic production of the anti breast cancer protein due to the insulin induced heterologous down regulation of the steroid receptor numbers in the neutrophils that not only resulted in the progesterone induced maspin synthesis, but also inhibited NO synthesis induced by the steroid in these cells. It may be speculated that in Type2 diabetes mellitus which causes hyperinsulinemia due to systemic insulin resistance might actually lead to worse prognostic outcome in breast cancer. On the other hand in Type1 diabetes where insulin synthesis is completely impaired might be beneficial in breast cancer due to maspin synthesis. ${ }^{30-33}$

Table I The effect of progesterone on the synthesis of NO and maspin in normal PR+ and PR- neutrophils pre incubated with insulin

\begin{tabular}{|c|c|c|c|c|}
\hline \multirow{2}{*}{ Addition } & \multicolumn{2}{|c|}{ Maspin (nM/6 $\times 10^{9}$ cells) } & \multicolumn{2}{|c|}{ NO $\left(\mu \mathrm{M} / 6 \times 10^{9}\right.$ cells $)$} \\
\hline & PR+ & PR- & PR+ & PR- \\
\hline Progesterone (25nM) & $2.329 \pm 0.012$ & 0 & $1.317 \pm 0.082$ & 0 \\
\hline Progesterone $(25 \mathrm{nM})+$ Insulin $(200 \mu \mathrm{U})$ & $1.410 \pm 0.002$ & 0 & $0.737 \pm 0.004$ & 0 \\
\hline
\end{tabular}

Table 2 The effect of progesterone on the synthesis of NO and maspin in Breast Cancer PR+ and PR- neutrophils pre incubated with insulin

\begin{tabular}{lllll}
\hline \multirow{2}{*}{ Addition } & \multicolumn{2}{l}{ Maspin $\left(\mathrm{nM} / 6 \times 10^{9}\right.$ cells $)$} & \multicolumn{2}{l}{ NO $\left(\boldsymbol{\mu M} / 6 \times 10^{9}\right.$ cells $)$} \\
\cline { 2 - 5 } & PR+ & PR- & PR+ & PR- \\
\hline Progesterone $(25 \mathrm{nM})$ & $1.138 \pm 0.024$ & 0 & $0.720 \pm 0.006$ & 0 \\
Progesterone $(25 \mathrm{nM})+\operatorname{Insulin}(200 \mu \mathrm{U})$ & $0.555 \pm 0.003$ & 0 & $0.313 \pm 0.002$ & 0 \\
\hline
\end{tabular}

\section{Acknowledgments}

None.

\section{Conflicts of interest}

Authors declare that there is no conflict of interest.

\section{References}

1. Schneider HP, Jackisch C. Potential benefits of estrogens and progestogens on breast cancer. Int J Fertil Womens Med. 1998;43(6):278-285.

2. Russo IH, Russo J. Role of hormones in mammary cancer initiation and progression. J Mammary Gland Biol Neoplasia. 1998;3(1):49-61.

3. Parsa P, Parsa B. Effects of reproductive factors on risk of breast cancer: a literature review. Asian Pac J Cancer Prev. 2009;10(4):545-550.

4. Iwasaki M, Otani T, Inoue M, et al. Role and impact of menstrual and reproductive factors on breast cancer risk in Japan. Eur J Cancer Prev. 2007;16(2):116-123.

5. Beato M, Klug J. Steroid hormone receptors: an update. Hum Reprod Update. 2000;6(3):225-236.

6. Maehle BO, CollettK, Tretli S, etal. Estrogen receptor beta an independent prognostic marker in estrogen receptor alpha and progesterone receptorpositive breast cancer? APMIS. 2009;117(9):644-650.

7. Rosa FE, Caldeira JR, Felipes J, et al. Evaluation of estrogen receptor alpha and beta and progesterone receptor expression and correlation with clinicopathologic factors and proliferative marker Ki-67 in breast cancers. Hum Pathol. 2008;39(5):720-730.

8. Lange CA, Sartorius CA, Abdel-Hafiz H, et al. Progesterone receptor action: translating studies in breast cancer models to clinical insights. BM Adv Exp Med Biol. 2008;630:94-111.

9. Cork DM, Lennard TW, Tyson CAJ. Alternative splicing and the progesterone receptor in breast cancer. Breast Cancer Res. 2008;10(3):207
10. Pichon MF, Pallud C, Brunet M, et al. Relationship of presence of progesterone receptors to prognosis in early breast cancer. Cancer Res. 1980;40(9):3357-3360.

11. Gelbfish GA, Davidson AL, Kopel S, et al. Relationship of estrogen and progesterone receptors to prognosis in breast cancer. Ann Surg. 1988;207(1):75-79.

12. Katzenellenbogen BS. Mechanisms of action and cross-talk between estrogen receptor and progesterone receptor pathways. J Soc Gynecol Investig. 2000;7(1 Suppl):S33-S37.

13. Freychet P, Roth J, Neville DM. Insulin receptors in the liver: specific binding of (125 I) insulin to the plasma membrane and its relation to insulin bioactivity. Proc Natl Acad Sci USA. 1971;68(8):1833-1837.

14. Basrawala Z, Alimirah F, Xin H, et al. Androgen receptor levels are increased by interferons in human prostate stromal and epithelial cells. Oncogene. 2006;25(19):2812-2817.

15. Kahn NN, Sinha AK. Down regulation of alpha 2 adrenergic receptor numbers in platelets by insulin. Biochim Biophys Acta. 1992;1134(3):292-296.

16. Dutta RAK, Kahn NN, Sinha AK. Interaction of receptors for prostaglandin E1/prostacyclin and insulin in human erythrocytes and platelets. Life Sci. 1991;49(16):1129-1139.

17. Kahn NN, Bauman WA, Hatcher VB, et al. Inhibition of platelet aggregation and the stimulation of prostacyclin synthesis by insulin in humans. Am J Physiol. 1993;265(6):2160-2167.

18. Kahn NN, Sinha AK. Stimulation of prostaglandin $E \neg 1$ binding to human blood platelet membrane by insulin and the activation of adenylate cyclase. J Biol Chem. 1990;265:4976-4981.

19. Ganguly BK, Bhattacharyya M, Halder UC, et al. The role of neutrophil estrogen receptor status on maspin synthesis via nitric oxide production in human breast cancer. J Breast Cancer. 2012;15(2):181-188.

20. Girish GV, Bhattacharya G, Sinha AK. The role of insulin dependent NO synthesis in the impaired production of maspin in human breast cancer. $J$ Cancer Res Clin Oncol. 2006;132(6):389-398. 
21. Tlaskalova-Hogenova H, Stepankova R. Development of antibody formation in germ-free and conventionally reared rabbits: the role of intestinal lymphoid tissue in antibody formation to E. coli antigens. Folia Biol (Praha). 1980;26(2):81-93.

22. Cox RD, Frank CW. Determination of nitrate and nitrite in blood and urine by Chemiluminiscence. J Anal Toxicol. 1982;6:148-152.

23. Klock JC, Bainton DF. Degranulation and abnormal bactericidal function of granulocytes procured by reversible adhesion to nylon wool. Blood. 1976;48(1):149-161.

24. Cook L, Ross AM, Knight GB, et al. Use of whole blood specimens for routine clinical quantitation of hepatitis $\mathrm{C}$ virus RNA does not increase assay sensitivity. J Clin Microbiol. 2000;38(12):4326-4331.

25. Zimmerman R, Paluch U, Sprinzl M, et al. Cell-free synthesis of the mitochondrial ADP/ATP carrier protein of Neurospora crassa. Eur J Biochem. 1979;99:247-252.

26. Engvall E, Perlmann P. Enzyme-linked immunosorbant assay, ELISA. 3. Quantitation of specific antibodies by enzymelabeled anti-immunoglobulin in antigen-coated tubes. J Immunol. 1972;109(1):129-135.

27. Scatchard G. The attractions of proteins for small molecules and ions Ann Y Acad Sci. 1949;51:660-672
28. Kiba T, Inamoto T, Nishimura T, et al. The reversal of recurrence hazard rate between ER positive and negative breast cancer patients with axillary lymph node dissection (pathological stage I-III) 3 years after surgery. BMC Cancer. 2008;8:323.

29. De Meyts P, Van Obberghen E, Roth J. Mapping of the residues responsible for the negative cooperativity of the receptor-binding region of insulin. Nature. 1978;273(5663):504-509.

30. Hojo T, AkiyamaY, Nagasaki K. Association of maspin expression with the malignancy grade and tumor vascularization in breast cancer tissues. Cancer Lett. 2001;171(1):103-110.

31. Liu T, Pemberton PA, Robertson AD. Three-state unfolding and selfassociation of maspin, a tumor-suppressing serpin. J Biol Chem. 1999;274(42):29628-19632.

32. Van den BHW, Leahey WJ, Lynch M, et al. Recombinant human interferon alpha increases oestrogen receptor expression in human breast cancer cells (ZR-75-1) and sensitizes them to the anti-proliferative effects of tamoxifen. Br J Cancer. 1987;55(3):255-257.

33. Abdul RJ, Mohammed JK, Laura H. Phase I Clinical Trial of Tamoxifen and Interferon Alpha in the Treatment of Solid Tumors. The Journal of Applied Research. 2004;4(3):464-469. 